Saúde e Pesquisa, Maringá (PR)

DOI: http://dx.doi.org/10.177651/1983-1870.2018v11n1p99-106

\title{
MUSCLE ADVERSE EVENTS AMONG USERS OF SIMVASTATIN IN PRIMARY HEALTH CARE: COLLABORATIVE DRUG THERAPY MANAGEMENT
}

\section{Marcos Francisco Pereira Lobrigatte}

Biosciences to Pharmacy, Department of Clinical Analysis and Biomedicine, State University of Maringa, Brazil.

\section{Glauco de Mello Nogueira}

Basic Health Unit, Department of Health, Peabiru, Brazil.

\section{Vinícius João Navarini}

Biosciences to Pharmacy, Department of Clinical Analysis and Biomedicine, State University of Maringa, Brazil

\section{Márcia Terezinha Lonardoni Crozatti}

Department of Biological Sciences, Federal University of Sao Paulo, Diadema, Brazil.

\section{Jorge Juarez Vieira Teixeira}

Doctor in Public Health from the University of São Paulo. Professor at the Federal University of São Paulo, for pharmacy. Biosciences to Pharmacy, Department of Clinical Analysis and Biomedicine, State University of Maringa, Brazil.
Autor correspondente

Marcos Francisco Pereira Lobrigatte

E-mail: marcosfpl@yahoo.com.br

\begin{abstract}
Collaborative drug therapy management in primary health care involves communication among the physician, pharmacist and user of simvastatin and can result in safer results regarding patient wellbeing. The aim of the study was to investigate muscle adverse events and risk factors related to simvastatin. For patients who developed muscle adverse events, collaborative drug therapy management was performed in an attempt to resolve the symptoms. A non-randomized case study was conducted at the single basic health unit in the city of Peabiru, Parana, Brazil, for a period of one year. Patients were interviewed using a structured form. To confirm muscle adverse events, the patient was referred to a physician and submitted to the suspension and return to treatment. Thyroid-stimulating hormone, creatine kinase and alanine aminotransferase exams were performed. A sample of 148 users of simvastatin was selected. Eleven patients had some type of simvastatinassociated muscle adverse event (myopathy), among whom seven had muscle symptoms (myalgia) and four had elevated creatine kinase, but were asymptomatic (asymptomatic myopathy). Collaborative drug therapy management focused on simvastatin for five patients with myalgia led to improvements in the quality of life of two patients.
\end{abstract}

KEY WORDS: Drug adverse event; Medication therapy management; Muscular disease; Primary health care; Simvastatin.

\section{EVENTOS ADVERSOS MUSCULARES ENTRE USUÁRIOS DE SINVASTATINA NA ATENÇÃO PRIMÁRIA EM SAÚDE: MANEJO COLABORÁTIVO DE TERAPIA MEDICAMENTOSA}

RESUMO: O manejo colaborativo de tratamento medicamentoso em atenção primária envolve a comunicação entre o médico, farmacêutico e o usuário de sinvastatina e pode levar a resultados mais seguros, favorecendo o bem-estar do paciente. O objetivo do estudo foi investigar eventos adversos musculares e fatores de risco para tais eventos, relacionados à sinvastatina. Para os pacientes que desenvolveram eventos adversos musculares, o manejo colaborativo foi realizada de forma a resolver os sintomas. Um estudo de caso não randomizado foi realizado na única unidade básica de saúde na cidade de Peabiru, Paraná, Brasil, por um período de um ano. Os pacientes foram entrevistados por meio de um formulário estruturado. Para confirmar os eventos adversos musculares, o paciente era encaminhado ao médico, sendo submetido à suspensão e retorno da sinvastatina. Foram realizadas dosagens do hormônio tireoestimulante, creatina quinase e alanina aminotransferase. Uma amostra de 148 usuários de simvastatina foi selecionada. Do grupo estudado, 11 pacientes tiveram algum tipo de evento adverso muscular (miopatia) associada à sinvastatina, entre os quais sete tiveram sintomas musculares (mialgia) e quatro apresentaram elevação da creatina quinase, mas eram assintomáticos 
(miopatia assintomática). O manejo colaborativo de terapia medicamentosa focada na sinvastatina para cinco pacientes com mialgia levou a melhoria na qualidade de vida de dois pacientes.

PALAVRAS-CHAVE: Evento adverso; Manejo da terapia medicamentosa; Doença muscular; Atenção primária em saúde; Sinvastatina.

\section{INTRODUCTION}

Statins are effective drugs used to reduce low-density lipoprotein cholesterol and diminish illness and mortality rates associated with coronary artery disease, making these drugs the basis for the treatment of atherosclerosis ${ }^{1,2}$. Despite the benefits, statins can cause adverse events, the most common of which involve muscles, followed by the liver ${ }^{3}$. Muscle adverse events may involve an asymptomatic increase in creatine kinase (CK), mild muscle complaints (pain, cramps, weakness) or even rhabdomyolysis, with kidney failure and the risk of death. Hepatic adverse events involve elevated levels of transaminases, but with no evidence of hepatotoxicity ${ }^{4}$.

Clinical trials indicate that statin-associated myalgia affects approximately $5.0 \%$ of patients, with similar rates regarding placebo5. The epidemiology of statin-associated myopathy is described little and generally directed toward rhabdomyolysis ${ }^{6}$. Epidemiological studies and intervention studies carried out in primary health care offer complementary findings, allowing the identification of possible adverse events during the follow up of patients. Collaborative primary health care involving communication among the physician, pharmacist and patient can provide safer results with regard to patient wellbeing ${ }^{7,8}$.

The aim of the study was to investigate muscle adverse events and risk factors related to the use of simvastatin among patients treated at a primary public healthcare service in a city of Brazil and manage the use of simvastatin for patients with muscle complaints (myalgia).

\section{METHODOLOGY}

A non-randomized case study was conducted at the single basic health unit in the city of Peabiru, Parana, Brazil, between August 2010 and August 2011, which had in 2010, 13.264 inhabitants. Approval by ethics committee $\mathrm{N}^{\circ} 448 / 2010$.

The inclusion criteria were age 40 years or older, either gender and continuous use of simvastatin for at least the previous 30 days. The following were the exclusion criteria to eliminate conditions that can increase the prevalence of musculoskeletal pain unrelated to simvastatin use or can mask musculoskeletal pain related to simvastatin use: concomitant use of fibrate, diagnosis of hypothyroidism, arthritis, arthrosis, sciatica, nonspecific pain pre-existing treatment with simvastatin and being bedridden?

All patients who met the inclusion criteria for the use of simvastatin were enrolled for the study (148 Patients). After application of the eligibility criteria and dropouts due to non-adherence to treatment, discontinuation based on medical orders, death, having moved to another city or refusal to participate, the final sample was made up of 92 individuals.

For authenticity verification and validity of the data collection instrument, a structured interview was conducted through a pre-test with ten patients with similar characteristics of the study, and they are not included in the final study.

Each patient was interviewed by the pharmacist at least four times either at the pharmacy of the basic healthcare unit or at home for an average period of one year. A structured chart was used to record sociodemographic and pharmaco-epidemiological data as well as diagnosed diseases, anthropometric data, musculoskeletal complaints, risk factors for simvastatinrelated muscle adverse events and the results of laboratory exams.

When a simvastatin-related muscle adverse event was suspected by the pharmacist, the patient was referred for medical consultation to diagnose or rule out this adverse event. The pharmacist provided the patient with a letter to bring to the medical consultation containing information relevant to clinical management, such as 
the location and duration of the muscle complaint, risk factors for simvastatin-related muscle adverse events, existing diseases, use of continuous medication (for the determination of drug interactions), laboratorial data, weight and height. The physician investigated the current muscle symptoms (type, location, time of onset, temporal pattern, triggers, aggravating agents and improvement factors, intensity, analgesic use), previous history and family background of muscle symptoms ${ }^{10}$.

After the medical consultation, if a patient presented possible simvastatin-related muscle adverse events, he/she was submitted to a cycle of suspension and return to treatment (Figure 1). A simvastatin-related muscle adverse event was only recorded if affirmative responses were received during all steps ${ }^{11}$. In positive cases of a muscle adverse event, hypothyroidism was investigated using the thyroid-stimulating hormone (TSH) exam. As this condition is a risk factor for myopathy, any patients with hypothyroidism were excluded from the study $^{12}$.

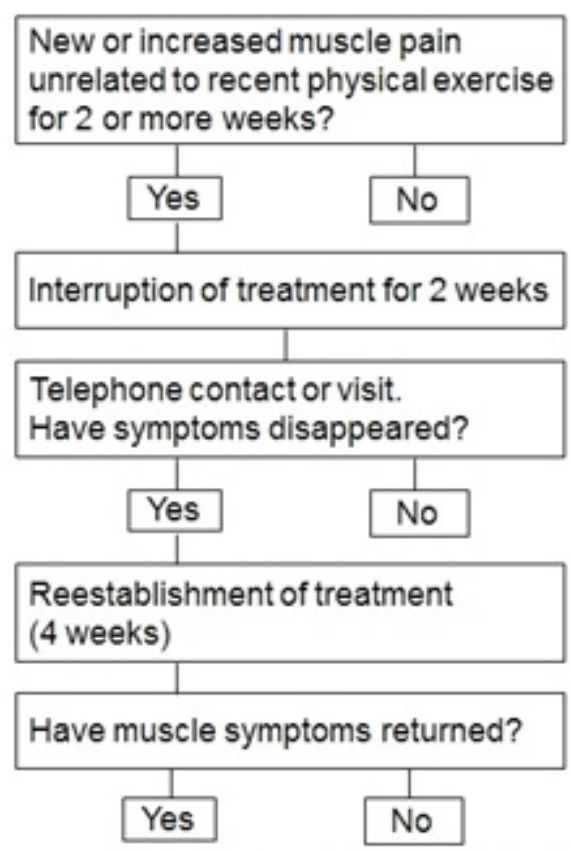

Figure 1. Steps for determination of muscle adverse events Adapted form Thompson et al. ${ }^{11}$

For patients who were positive for muscle adverse events and negative for thyroid disease, clinical management was performed by the physician in an attempt to reduce the risk factors and consequently reduce or eliminate the simvastatin-related muscle adverse event. For the clinical intervention, the physician also considered the cardiovascular protection that simvastatin provides for each patient.

Creatinekinase(CK) andalanineaminotransferase (ALT) exams were performed during the second and fourth interviews (approximate interval of 6 months). These exams were not requested prior to initiating treatment with simvastatin, because when the study began to be developed, patients were already receiving treatment. For each case identified with abnormal results, the investigation was performed with the physician. An abnormal CK result was attributed to simvastatin if could not be explained by physical exercise, alcohol abuse, use of cocaine, seizure, acute myocardial infarction, intra-muscular injection or surgery. Polymyositis and dermatomyositis were investigated by the physician and on the patient charts ${ }^{13,14}$. Among patients with elevated $\mathrm{CK}$, hypothyroidism was investigated using the TSH exam to exclude these patients in cases of a positive result ${ }^{12}$. An abnormal ALT result was attributed to simvastatin if it could not be explained by liver disease $\mathrm{e}^{14}$. Among patients with altered ALT, further medical evaluation was recommended.

Adverse events related to statins may be favoured by certain risk factors that are poorly understood ${ }^{15}$. With regard to simvastatin, the risk factors for myopathy are presented in Table $1^{16-18}$.

The Epidata $3.1^{\circledR}$ program was used to organise the data. Descriptive analysis with frequency distribution, calculation of odds ratios and Fisher's exact test was used, with statistical significance of $p<0.05$.

\section{RESULTS}

Among the 92 patients analysed, 53 were women, mean age was 63.4 years ( \pm 10.7 ; range: 42 to 86 years) and 51 made use of simvastatin $40 \mathrm{mg}$.

As seen in Table 1, polypharmacy was the most frequent risk factor $(\mathrm{n}=63)$, followed by the female gender $(n=53)$ and diabetes mellitus $(n=39)$. 
Table 1. Risk factors for myopathy

\begin{tabular}{lcc}
\hline \multicolumn{1}{c}{ Variables } & N (92)* & N (7)** \\
\hline Female gender & 53 & 4 \\
$\geq 80$ years of age & 08 & 1 \\
Polypharmacy use $(\geq 5)$ & 63 & 4 \\
High dose (simvastatin $80 \mathrm{mg})$ & 10 & 1 \\
Kidney failure & 4 & 1 \\
Liver failure & 1 & 0 \\
Diabetes mellitus & 39 & 2 \\
Alcohol abuse & 0 & 0 \\
BMI $\leq 18.5$ & 0 & 0 \\
Surgery & 2 & 0 \\
Extensive physical exercise & 1 & 0 \\
Possible drug interaction & 14 & 2 \\
\hline
\end{tabular}

* Total of patients. ** Patients with myalgia related to simvastatin.

Among the 92 patients, 11 had some type of simvastatin-related muscle adverse event (myopathy), among whom 7 had muscle symptoms (myalgia) and four had elevated CK, but were asymptomatic. Regarding the seven patients with muscle symptoms, five had altered CK $1 \mathrm{X}$ to $3 \mathrm{X}$ above the upper limit of normality (ULN) and two only had muscle symptoms. There were no cases of severe myositis or rhabdomyolysis.

Table 2 shows that regardless of the accumulation of risk factors for the presence of myalgia related to simvastatin, there was no statistically significant association.

Table 2. Association of risk factors for myalgia related to simvastatin

\begin{tabular}{c|c|c|c|c}
\hline $\begin{array}{c}\text { Number of } \\
\text { risk } \\
\text { factors }\end{array}$ & $\begin{array}{c}\text { Patients wi- } \\
\text { thout myal- } \\
\text { gia (85) }\end{array}$ & $\begin{array}{c}\text { Patients } \\
\text { with myal- } \\
\text { gia (7) }\end{array}$ & OR (CI 95\%) & $\begin{array}{c}\boldsymbol{p}- \\
\text { value* }\end{array}$ \\
\hline 1 & 24 & 3 & 1 & \\
2 & 32 & 1 & $\begin{array}{c}3.9(0.4 \\
-108.3)\end{array}$ & 0.468 \\
3 & 22 & 2 & $\begin{array}{c}1.4(0.2- \\
12.4)\end{array}$ & 1.110 \\
4 & 7 & 1 & $\begin{array}{c}0.9(0.1- \\
26.2)\end{array}$ & 1.330 \\
\hline
\end{tabular}

* Fisher's exact test with significance for $p<0.05$
Table 3 display the interventions made individually to patients and outcomes.

Table 3. Distribution of collaborative interventions and outcome of patients

\begin{tabular}{|c|c|c|}
\hline Patients & Collaborative interventions & Outcome \\
\hline 1 & $\begin{array}{l}\text { No intervention was } \\
\text { performed }\end{array}$ & $\begin{array}{l}\text { Mild and intermittent } \\
\text { muscle symptoms }\end{array}$ \\
\hline 2 & $\begin{array}{l}\text { No intervention was } \\
\text { performed }\end{array}$ & $\begin{array}{l}\text { Muscle symptoms } \\
\text { disappeared after a time }\end{array}$ \\
\hline 3 & $\begin{array}{l}\text { Simvastatin dose was in- } \\
\text { creased }(20 \mathrm{mg} \text { to } 40 \mathrm{mg}) \\
\text { to achieve the therapeutic } \\
\text { target of blood cholesterol }\end{array}$ & $\begin{array}{l}\text { No worsening of the } \\
\text { muscle symptoms }\end{array}$ \\
\hline 4 & $\begin{array}{l}\text { Simvastatin dose was } \\
\text { lowered }(40 \mathrm{mg} \text { to } 20 \mathrm{mg} \text { ) } \\
\text { for two months } \\
\text { Return to the dose of } 40 \mathrm{mg}\end{array}$ & $\begin{array}{l}\text { No improvement in the } \\
\text { muscle symptoms was } \\
\text { seen } \\
\text { Muscle symptoms } \\
\text { remained similar }\end{array}$ \\
\hline 5 & $\begin{array}{l}\text { Replace simvastatin } 40 \mathrm{mg} \\
\text { with atorvastatin } 5 \mathrm{mg} \text { for } \\
30 \text { days } \\
\text { Atorvastatin dose was } \\
\text { increased }(5 \mathrm{mg} \text { to } 10 \mathrm{mg})\end{array}$ & $\begin{array}{l}\text { Patient remained } \\
\text { symptom-free } \\
\text { The patient continued to } \\
\text { be symptom-free }\end{array}$ \\
\hline 6 & $\begin{array}{l}\text { Simvastatin dose was lowered } \\
(80 \mathrm{mg} \text { to } 40 \mathrm{mg})\end{array}$ & $\begin{array}{l}\text { Muscle symptoms } \\
\text { disappeared }\end{array}$ \\
\hline 7 & Suspended simvastatin & $\begin{array}{l}\text { Partial improvement in } \\
\text { muscle symptoms }\end{array}$ \\
\hline
\end{tabular}

Among the 92 patients, three who used simvastatin $40 \mathrm{mg}$ had altered ALT during only one of the determinations and were without muscle symptoms or jaundice (normochromic skin, sclera, urine and faeces). Two patients had alterations not surpassing 2X ULN, with normal subsequent determinations. One patient had 5X ULN and was referred to the physician, and total and fractionated bilirubin were normal.

\section{DISCUSSION}

The prevalence of muscle symptoms (myalgia) among the patients analysed was $7.6 \%(\mathrm{n}=7)$, which is similar to rates described in previous observational studies ${ }^{19-21}$. The $12.0 \%(\mathrm{n}=11)$ prevalence rate of myopathy (which includes patients with muscle symptoms independent of the CK level and clinically 
asymptomatic patients with abnormal $\mathrm{CK}$ ) is difficult to compare with findings reported in the literature, as most studies were not designed specifically to detect elevated CK $<10 \mathrm{X}$ ULN $^{22-23}$. Due to the lack of a consensus on the definition of the nomenclature of muscle adverse events, it is difficult to obtain precise estimates and compare prevalence rates. ${ }^{16}$ Although there were no cases of a clinically important increase in CK (CK > 10X ULN associated with myalgia), one cannot discard the possibility of muscle injury and a negative effect on the quality of life of the patients ${ }^{5,24}$.

Regarding the association of risk factors for the development of myalgia related to simvastatin, there was no statistical significance. Other studies have shown results contrary to our findings ${ }^{16,19}$. We consider that the number of risk factors when added (or accumulated) may put the patient at increased risk for the development of myalgia. We believe that one explanation for our findings, compared to published studies, is due to the small study population.

Elevated ALT was only important in one patient (ALT > 3X ULN). Even with no evidence of liver damage, the physician reduced the dose of simvastatin to $20 \mathrm{mg}$ and the subsequent ALT determination was within the range of normality. This finding seems to show a low risk for a clinically important rise in ALT, which is in agreement with previous studies reporting a frequency of $0.3 \%$ to $2.4 \%{ }^{14,25}$.

The concern with myositis and rhabdomyolysis leads some physicians to interrupt statin therapy prior to reaching CK levels of 10X ULN ${ }^{26}$. Even with a moderate elevation in CK (2.5X to 5X ULN), it is not clear whether the discontinuation of treatment is beneficial to the patient due to the resolution of the muscle problem or harmful due to the interruption of the medication, which has a protective effect on the cardiovascular system ${ }^{14}$. Recent recommendations have stressed the importance of the careful monitoring of patients who present mild muscle problems, even with no rise in $\mathrm{CK}$, as their quality of life may be reduced and/or they may not adhere to treatment ${ }^{24}$.

Among the seven patients in the present study who exhibited muscle symptoms, no intervention was performed on two of them (patients 1 and 2) due to the mild, intermittent symptoms, which had no negative effect on their activities of daily living or simply disappeared after a time.

Clinical management, with collaborative interventions between the physician and pharmacist, was the recourse for the other five patients with muscle symptoms (patients 3 to 7). In patient 3, with polypharmacy as a risk factor, the physician increased the simvastatin dose (20 mg to $40 \mathrm{mg}$ ) to achieve the therapeutic target of blood cholesterol, with no worsening of the muscle symptoms and with a slight increase in $\mathrm{CK}$, which returned to normal levels without the use of simvastatin $40 \mathrm{mg}$. The patient subsequently returned to the continuous use of simvastatin $40 \mathrm{mg}$.

In an attempt to resolve muscle symptoms in patient 4 (risk factors: polypharmacy and diabetes mellitus), the physician lowered the simvastatin dose ( $40 \mathrm{mg}$ to $20 \mathrm{mg}$ ), but no improvement was seen for two months. In further discussions among the physician, pharmacist and patient, the decision was made to return to the dose of $40 \mathrm{mg}$ and the muscle symptoms remained similar.

Patient 5 developed muscle adverse events after seven years of using simvastatin $40 \mathrm{mg}$. The risk factors were polypharmacy, female gender and kidney failure. Myalgia was permanent in both the upper and lower limbs, with negative effects on activities of daily living and intolerance to simvastatin. The physician's intervention consisted of the replacement of the medication with atorvastatin $5 \mathrm{mg}$ and the patient remained symptomfree for 30 days. The dose was then increased to $10 \mathrm{mg}$. The patient continued to be symptom-free and CK was altered, but remained within acceptable limits $(\mathrm{CK}<10 \mathrm{X}$ $\mathrm{ULN})^{5,27}$.

Patient 6 was exposed to multiple risk factors (> 80 years, $80 \mathrm{mg}$, polypharmacy and interaction with amlodipine). The physician lowered the dose (80 $\mathrm{mg}$ to $40 \mathrm{mg}$ ), resulting in the elimination of muscle symptoms.

In patient 7 (risk factors: female gender, interaction with amlodipine and diabetes mellitus), partial improvement in muscle symptoms occurred after the physician suspended simvastatin. However, after three months without simvastatin, the symptoms returned with greater intensity in the entire body, with a higher CK level. 
These findings indicate that the symptoms were less likely related to simvastatin. It is not clear whether alterations in genes related to muscle function predispose individuals to the development of myopathy with the use of statins or whether statins are capable of unmasking a hidden myopathy ${ }^{28-29}$.

Among the four patients with an asymptomatic elevation in CK, none exceeded 3X ULN. All these patients were women, supporting the hypothesis that the female gender is risk factor for statin-associated myopathy. The dose of one of these four patients was increased (20 $\mathrm{mg}$ to $40 \mathrm{mg}$ ) by the physician, with an increase in CK from $271 \mathrm{U} / \mathrm{L}$ to $390 \mathrm{U} / \mathrm{L}$. Following the suspension of simvastatin for two months, CK was lowered to $186 \mathrm{U} / \mathrm{L}$. These patients were instructed by the pharmacist and physician to continue treatment and report any muscle symptoms to the physician. This type of research allows viewing the positive results of an intervention and a closer relationship among the patient, pharmacist and doctor, providing the greatest benefit from drug therapy. It is believed that the present study demonstrated clinical significance despite the small number of patients with satisfactory results.

Some limitations of the present study should be considered, such as the small sample size, as approximately one third of patients were either excluded or lost. The absence of baseline testing for ALT and CK constitutes an important bias, as the study was conducted under conditions of routine work. The interviews were conducted on average every three months, requiring the patient to recall past information on muscle symptoms, which can lead to recall bias. Another important limitation was the lack of statistical analysis, as the data were only analysed descriptively. Despite these limitations, the results may be important to clinical practice and the welfare of patients, especially in primary health care.

\section{CONCLUSION}

It is believed that the results of the present study on drug therapy follow up, the identification of risk factors by the pharmacist and the clinical interventions by the physician could contribute to reducing or resolving safety issues related to simvastatin. Collaborative management of therapy among the physician, pharmacist and patient led to an increase in the quality of life of two patients. It is important for health professionals to remain vigilant regarding potential adverse events caused by simvastatin.

Recommendations for the safe use of statins: before initiating treatment with simvastatin, evaluate risk factors (sex, age, high dose, polypharmacy, drug interactions, liver and kidney failure, diabetes mellitus, alcohol abuse, BMI $\leq 18.5$, surgery and extensive physical exercise), determine baseline ALT and CK levels and investigate previous muscle complaints and aches. Thus, if a patient develops myopathy, it would be possible to obtain more accurate data and objective parameters for the correct diagnosis and management of the problem.

\section{REFERENCES}

1. Vaughan CJ, Gotto AM. Update on statins: 2003. Circulation. 2004; 110: 886-892. DOI: 10.1161/01. CIR.0000139312.10076.BA.

2. Simpson RJJr, Mendys P. The effects of adherence and persistence on clinical outcomes in patients treated with statins: a systematic review. J Clin Lipidol. 2010; 4: 462-471. DOI: 10.1016/j.jacl.2010.08.026.

3. Bellosta S, Paoletti R, Corsini A. Safety of statins: focus on clinical pharmacokinetics and drug interactions. Circulation. 2004; 109 (Suppl 1): 50-57. DOI: 10.1161/01.CIR.0000131519.15067.1f.

4. Vuppalanchi R, Teal E, Chalasani N. Patients with elevated baseline liver enzymes do not have higher frequency of hepatotoxicity from lovastatin than those with normal baseline liver enzymes. Am J Med Sci. 2005; 329:62-5. DOI: 10.1097/00000441-20050200000002 .

5. Jacobson TA. Toward "pain-free" statin prescribing: clinical algorithm for diagnosis and management of myalgia. Mayo Clin Proc. 2008;83:687-700. DOI: 10.4065/83.6.687.

6. Corsini A. Statin-related muscle complaints: an underestimated risk. Cardiovasc Drugs Ther. 2005; 19: 379-381. DOI: 10.1007/s10557-005-6352-1. 
7. Lalonde L, Hudon E, Goudreau J, Bélanger D, Villeneuve J, Perreault S, et al. Physician-pharmacist collaborative care in dyslipidemia management: The perception of clinicians and patients. Res Social Adm Pharm. 2011; 7: 233-245. DOI: 10.1016/j. sapharm.2010.05.003.

8. Farris KB, Côté I, Feeny D, Johnson JA, Tsuyuki RT, Brilliant S, Dieleman S. Enhancing primary care for complex patients. Demonstration project using multidisciplinary teams. Can Fam Physician. 2004; 50: 998-1003. Available in http://www.cfp.ca/content/ cfp/50/7/998.full.pdf.

9. Buettner C, Davis RB, Leveille SG, Mittleman MA, Mukamal KJ. Prevalence of musculoskeletal pain and statin use. J Gen Intern Med. 2008; 23: 1182-1186. DOI: 10.1007/ s11606-008-0636-7.

10. Franc S, Dejager S, Bruckert E, Chauvenet M, Giral P, Turpin G. A comprehensive description of muscle symptoms sssociated with lipid-lowering drugs. Cardiovasc Drugs Ther. 2003; 17: 459-465.

11. Thompson PD, Parker BA, Clarkson PM, Pescatello LS, White CM, Grimaldi AS, Levine BD, Haller RG, Hoffman EP. A randomized clinical trial to assess the effect of statins on skeletal muscle function and performance: rationale and study design. Prev Cardiol. 2010; 13: 104-111. DOI: 10.1111/j.1751-7141.2009.00063.x.

12. Armitage J. The safety of statins in clinical practice. Lancet. 2007; 370: 1781-1790. DOI: 10.1016/S01406736(07)60716-8.

13. Venero CV, Thompson PD. Managing statin myopathy. Endocrinol Metab Clin North Am. 2009; 38: 121-136. DOI: 10.1016/j.ecl.2008.11.002.

14. Smith CC, Bernstein LI, Davis RB, Rind DM, Shmerling RH. Screening for statin-related toxicity the yield of transaminase and creatine kinase measurements in a primary care setting. Arch Intern Med. 2003 ; 163: 688692. Available in http://jamanetwork.com/journals/ jamainternalmedicine/fullarticle/215286.
15. Grundy SM. Can statins cause chronic low-grade myopathy? Ann Intern Med. 2002; 137: 617-618. DOI: 10.7326/0003-4819-137-7-200210010-00015.

16. Chatzizisis YS, Koskinas KC, Misirli G, Vaklavas C, Hatzitolios A, Giannoglou GD. Risk factors and drug interactions predisposing to statin-induced myopathy: implications for risk assessment, prevention and treatment. Drug Saf, 2010; 33: 171-187. DOI: 10.2165/11319380-000000000-00000.

17. Mosshammer D, Lorenz G, Meznaric S, Schwarz J, Muche R, Mörike K. Statin use and its association with musculoskeletal symptoms - a cross-sectional study in primary care settings. Family Practice. 2009; 26: 88-95. DOI: $10.1093 /$ fampra/cmp006.

18. Shek A, Ferrill MJ. Statin-fibrate combination therapy. Ann Pharmacother. 2001; 35: 908-917. DOI: 10.1345/ aph.10315.

19. Bruckert E, Hayem G, Dejager S, Yau C, Begaud B. Mild to moderate muscular symptoms with highdosage statin therapy in hyperlipidemic patients - the PRIMO study. Cardiovasc Drugs Ther. 2005; 19: 403414. DOI: 10.1007/s10557-005-5686-z.

20.de Sauvage Nolting PR, Buirma RJ, Hutten BA, Kastelein JJ. Two-year efficacy and safety of simvastatin $80 \mathrm{mg}$ in familial hypercholesterolemia (the Examination of Probands and Relatives in Statin Studies with Familial Hypercholesterolemia [ExPRESS FH]). Am J Cardiol. 2002; 90: 181-184. DOI: 10.1016/S0002-9149(02)02449-9.

21. Nichols GA, Koro CE. Does statin therapy initiation increase the risk for myopathy? An observational study of 32,225 diabetic and nondiabetic patients. Clin Ther. 2007; 29: 1761-1770. DOI: 10.1016/j. clinthera.2007.08.022.

22. Bays H. Statin safety: an overview and assessment of the data - 2005. Am J Cardiol. 2006; 97(Suppl 1): 6-26. DOI: 10.1016/j.amjcard.2005.12.006

23. Rosenson RS. Current overview of statin-induced myopathy. Am J Med. 2004; 116: 408-416. DOI: 10.1016/j.amjmed.2003.10.033. 
24. Thompson PD, Clarkson PM, Rosenson RS. National Lipid Association Statin Safety Task Force Muscle Safety Expert Panel. An assessment of statin safety by muscle experts. Am J Cardiol. 2006; 97 (Suppl 1): 6976. DOI: 10.1016/j.amjcard.2005.12.013.

25. Third Report of the National Cholesterol Education Program (NCEP) Expert Panel on Detection, Evaluation, and Treatment of High Blood Cholesterol in Adults (Adult Treatment Panel III) Final Report. Circulation. 2002; 106: 3143-3421. Available in http:// circ.ahajournals.org/content/106/25/3143.long.

26. Glueck CJ, Rawal B, Khan NA, Yeramaneni S, Goldenberg N, Wang P. Should high creatine kinase discourage the initiation or continuance of statins for the treatment of hypercholesterolemia? Metabolism. 2009; 58: 233-238. DOI: 10.1016/j. metabol.2008.09.019.

27. Rallidis LS, Fountoulaki K, Anastasiou-Nana M. Managing the underestimated risk of statin-associated myopathy. Int J Cardiol. 2011; 159: 169-176. DOI: 10.1016/j.ijcard.2011.07.048.

28. Baker SK, Vladutiu GD, Peltier WL, Isackson PJ, Tarnopolsky MA. Metabolic myopathies discovered during investigations of statin myopathy. Can J Neurol Sci. 2008 ; 35: 94-97.

29. Echaniz-Laguna A, Mohr M, Tranchant C. Neuromuscular symptoms and elevated creatine kinase after statin withdrawal. N Engl J Med. 2010; 362: 564-565. DOI: 10.1056/NEJMc0908215.

Recebido em: 08/08/2017

Aceito em: 22/02/2018 